\title{
E-PORTFOLIO AS A TOOL FOR PROFESSIONAL DEVELOPMENT AND ASSESSMENT OF THE PROSPECTIVE SINGERS
}

\author{
Dmytro Lievit \\ $\mathrm{PhD}$ in Philosophy, Associate Professor, \\ Borys Grinchenko Kyiv University, \\ Kyiv, Ukraine, \\ ORCID ID 0000-0003-3237-6427 \\ d.lievit@kubg.edu.ua
}

\begin{abstract}
This article examines the role of e-portfolios as digital assessment tools in enhancing the quality of student learning outcomes in higher education. E-portfolios tap into the potential of digital technologies to support students' self-monitoring, self-evaluation, and sharing of learning. Thus e-portfolios have been reported as bringing about improvements in prospective singers' learning. On the other hand, existing research also shows challenges for university teachers when adopting e-portfolio assessment. The issue of using e-portfolio assessment is currently being discussed in national and foreign studies (D. Alfimov, N. Mykhailova, M. Ostrenko, O. Pichkur, N. Savina, I. Shalyhina, E. Heinrich, M. Bhattacharya, R. Rayudu, S. Peacock, L. Gordon, S. Murray, K. Morss). To formulate strategies for optimising the learning potential of e-portfolios, a landscape review of research literature is conducted to address the research question about how e-portfolios are used as digital assessment tools to enhance the quality of learning outcomes in higher education.

The article presents an overview of e-portfolios as digital assessment tools. A typology of eportfolios is then presented to analyse the situations where e-portfolios are applied in higher education. The chapter goes on to argue for two essential affordances of e-portfolios, namely: empowerment and ownership of learning for students, and feedback and interactivity by drawing on digital technology. This is followed by a discussion of challenges and opportunities of e-portfolios in meeting conventional assessment criteria, including: reliability, validity, authenticity, and honesty. Key pedagogical factors influencing the use of e-portfolios as digital assessment are then examined. The author distinguishes the following factors: students' motivation for engaging with e-portfolios, dual roles of e-portfolios in assessment of learning and assessment for learning, possibility of students lacking the capacity for self-reflection, potentially insufficient teacher guidance and support.
\end{abstract}

Key words: e-portfolio; higher education; prospective singers; assessment; criteria; pedagogical factors.

Problem setting in general. The introduction of competence approach in preparing future professionals is one of the priorities of modernization of the national higher education system today. In particular, improving the training of prospective singers, in addition to upgrading the content, involves updating traditional forms, methods and means of teaching students with the use of innovative educational technologies. In higher education, although traditional high-stakes assessments are still the dominating measures of a student's learning, education leaders and policy-makers are beginning to pay more attention to alternative forms of assessments as they may play an important role in helping students to meet the needs of today's globalised, technology-rich knowledge society. Digital technologies, as approaches that enable 
E-Portfolio as a Tool for Professional Development and Assessment of the Prospective Singers

educational innovations, offer many opportunities for the provision of assessment that captures less tangible competences such as critical thinking or self-reflection. As such, e-portfolios, an outcome of the digitisation of paper-based portfolios, have been adopted as digital assessment tools in a growing number of universities around the world.

The latest papers and publications on the problem. The researchers consider the portfolio as a method of studying (V. Devisylov, N. Zaiachkivska, H. Piatakova), pedagogical technology or a combination of technologies (D. Alfimov, N. Mykhailova, M. Ostrenko, O. Pichkur, N. Savina, I. Shalyhina), method and technology (T. Berezhna, O. Pichkur), the form of organization of teaching (K. Osadcha), method or form of control (H. Holub, I. Knysh, M. Choshanov, I. Shalyhina), the instrument of evaluation (H. Holub, M. Pinska, O. Churakova, I. Shalyhina), an alternative way of evaluating academic achievement of students (V. Zahvozdkin, N. Zelenko, A. Mohylevska, T. Tataryntseva) method of evaluating competencies (O. Pinchuk), a means of monitoring individual achievements or alternative form of examination (T. Novykova, M. Pinska, O. Prutchenkov, O. Semenov)

Portfolios are used in many disciplines and although there are numerous definitions in the literature, in general a portfolio can be described as, a purposeful compilation and reflection of one's work, efforts and progress (Green, Wyllie, \& Jackson, 2014). In addition, there are different types of portfolio including assessment, employment, learning, and teaching portfolios, the format ultimately depending on the purpose for which it is developed.

The learning portfolio is seen as an "authentic" form of assessment by providing the means to assess students' ability to set their own goals, think critically, solve complex problems, work collaboratively and undertake reflective practice. The electronic portfolio or e-portfolio, an adaptation of the original paper-based portfolio in digital format is a more recent phenomenon not only providing students with a repository for collection and presentation of their work but also a mechanism for documenting growth and achievement of professional knowledge and skills.

The e-portfolio makes use of a variety of electronic media as well as links to external sources. While e-portfolios are created through a similar process to print based portfolios, e-portfolios have a number of advantages over print based portfolios including the ability to store, organise and reorder contents quickly and easily; provide opportunities to integrate student course work; their ability to form the basis for collaboration; the potential for development of information management, self organisation, planning, and presentation skills. The concept of digital or e-portfolio goes beyond text and still images only. One can incorporate multimedia to demonstrate knowledge and skills.

While retaining the benefits of traditional paper-based portfolios by enabling students' application of theory to practice and facilitating their goal-setting and reflection on learning (Lorenzo \& Ittelson, 2005), e-portfolios offer additional flexible functionalities. These range from easy storage, management, and sharing of digitalised 
E-Portfolio as a Tool for Professional Development and Assessment of the Prospective Singers

artefacts, through on-going planning, monitoring, and reflection on learning experience, to assessment and feedback on learning evidence by multiple stakeholders (i.e., teachers, students, employers, and/or accreditation bodies) (Green, Wyllie, \& Jackson, 2014). Besides flexibility, e-portfolios afford scalability. Scalability is reflected in the types of content uploaded or linked (e.g., text, graphics, audio, and video) as well as by the number and size of those files - with the advent of cloud storage, the scalability of e-portfolios has been enhanced considerably. E-portfolios' scalability also refers to their ability to grow and evolve over time, which could be extended throughout the author's formal education and lifelong learning. The flexible and scalable nature of e-portfolios makes them a viable option for promoting assessment innovations. Examples of such innovations include collectively constructed web-based e-portfolios that allow students' mutual support via peer-feedback (Barbera, 2009), self-assessment of artefacts and reflection that assist in students' selfimprovement in light of assessment criteria and learning goals (Chang, Liang, \& Chen, 2013), and continuous teacher guidance and feedback that scaffold students' learning progress.

In the article we make an attempt to outline the benefits of using e-portfolios in prospective singers' training, define the role of e-portfolios as digital assessment tools, distinguish the challenges and opportunities and factors influencing effective implementation of e-portfolios for assessment that constitute the purpose of the article.

Presentation of basic research material. Different types of e-portfolios have been discussed in the literature. While some e-portfolios contain samples of "less-thanperfect" and "in-progress" products as well as self-diagnoses, other e-portfolios display a student's best work. The varying ways of typifying e-portfolios reflect the different purposes and target audiences of e-portfolios. This section identifies and examines the uses of five major types of e-portfolios that are commonly adopted in higher education: e-portfolios for classroom learning, e-portfolios for accreditation and benchmarking, e-portfolios for employment, e-portfolios for work place learning, and e-portfolios as personal development profile.

Not every assessment method is universally valid for all kinds of learning outcomes. When the intended learning outcomes in higher education today go beyond the mastery of academic knowledge, assessment methods must be aligned to cultivating students' higher-order thinking skills and their real-world competencies.

In this section, the rationale for using e-portfolios as digital assessment tools in higher education is discussed in relation to the role of e-portfolios to afford:

- empowerment and ownership of learning for students;

- feedback and interactivity by drawing on digital technology.

Realising these two capacities is crucial for giving students learning support when they are engaged with e-portfolios; the possibility to afford such capacities is derived from the key features of e-portfolios that draw on digital technologies and portfolio pedagogy. The remainder of the section discusses the aforementioned 
E-Portfolio as a Tool for Professional Development and Assessment of the Prospective Singers

rationale and proposes using these two capacities as essential criteria to gauge the effectiveness of e-portfolios used as digital assessment tools.

Students who take ownership of learning become a driving force of their own learning. The role of e-portfolios as an enabler for empowerment and ownership of learning is based on two key affordances:

- the provision of a flexible structure to facilitate students' personalisation of learning in e-portfolio construction;

- the support for students' engagement in self-regulated learning.

The self-regulation learning process can be embedded in e-portfolio tasks that involve students in an iterative cycle in which students are required to (Heinrich et al., 2007; Peacock et al., 2010):

- compose a learning contract/journal that plans learning activities related to desired learning goals;

- undertake activities and construct artefacts as evidence of participating in the activities;

- write learning journals to self-reflect on what experiences have been gained in the activities, and how the experiences assist in gaining new understanding of course / programme-related knowledge / competency, and self-assess what progress has been made, and what further improvements are necessary in the subsequent steps of achieving learning goals.

It takes students considerable time and effort, and requires appropriate learning strategies, to create and self-manage e-portfolios that are personally meaningful to them. The research literature has reported other difficulties, such as some students' incompetence in dealing with the technical side of e-portfolio assessment, lack of motivation to engage in self-reflection and self-assessment of their learning, or lack of specific guidelines on setting learning goals and how to meet them.

There is evidence showing that students learn better when they receive quality feedback rather than marks alone ( $\mathrm{Li} \&$ De Luca, 2014). Yet, the extent to which feedback is attended to and acted upon by students is highly depend on whether they are supported through sufficient teacher-student and peer dialogues around learning. Due to the interactive nature of Web 2.0 technologies, e-portfolios afford: the provision of recurring, interactive feedback, and the encouragement of collective knowledge building through peer learning.

As an authentic alternative to standardised assessment, the extent to which eportfolios offer data to inform curriculum, teaching, and assessment has been debated in relation to the conventional criteria of assessment, which include reliability, validity, authenticity, and honesty. Furthermore, because of the inherent tensions associated with e-portfolios' multiple purposes and uses as discussed earlier, applying these criteria to e-portfolios brings about both opportunities and challenges for teachers, students, and administrators (Strudler \& Wetzel, 2005).

The twin criteria of reliability and validity have originated from traditional assessment influenced by educational measurement research, which stresses the 
E-Portfolio as a Tool for Professional Development and Assessment of the Prospective Singers

scientific rigor of standardised tests as psychometric measurements of student performance in given subject areas. When using e-portfolios, reliability and validity imply the provision of specific guidelines for students on the kinds of e-portfolio contents (e.g., artefacts, learning contracts, reflective journals, and learner profile) and the formats for presenting contents, as well as assessors' use of rubrics to evaluate student performance systematically (Strudler \& Wetzel, 2005).

Reliability in traditional assessment refers to the consistency or stability among two or more repeated assessment results on the same item across different assessors, time points, and contexts (Chang et al., 2013). The two facets of this criterion are internal reliability (or test-retest reliability), which denotes the consistency of assessment results given by the same assessor, and external reliability, which refers to the consistency of assessment results across different assessors, often expressed in terms of inter-rater reliability.

Past studies have identified different levels of reliability in e-portfolio assessment. Research evidence shows that the process of e-portfolio construction lends itself to various threats to reliability. The prolonged process in which students setting learning goals, collecting artefacts, and engaging in continuous reflections, though affording important learning benefits and rich description of learning progression, produces a high volume of data presented in varied digital formats, making it difficult for assessors to reach consistent judgments (Strudler \& Wetzel, 2005). The strategies of involving students in discussing exemplars and rubrics to clarify criteria and standards, providing training for assessors in scoring with rubrics, and establishing inter-rater reliability are suggested to overcome challenges in attaining reliability.

Validity is defined as the degree of accuracy of assessment results in evaluating expected properties and functions required of students (Chang et al., 2013). Validity in e-portfolio assessment is then the extent to which e-portfolio contents can accurately reflect students' achievements. From a traditional assessment perspective, validity in e-portfolio assessment can be established by examining the correlation between assessment results from e-portfolios and results from other assessments, such as endof-term examinations and essays.

Existing research highlights tensions between reliability and validity in eportfolio assessment. One such tension is over-emphasis on reliability at the expense of validity. For example, prescribing the contents to be included, the kinds of digital technologies for presenting contents, and aspects of learning experiences to reflect upon can enhance reliability; however, such guidelines may somehow dampen students' enthusiasm for e-portfolios and thus reduce validity (Strudler \& Wetzel, 2005). Teachers and administrators would have multiple beliefs about the nature and purpose of assessment mediated by e-portfolios, hence careful considerations are necessary in maintaining appropriate balance between reliability and validity.

Authenticity and honesty are discussed as conventional assessment criteria, since they are derived from traditional paper-based portfolios, which are a kind of authentic assessment. Authentic assessment is a collection of assessments that employ openended tasks (e.g., case studies, projects, and practicums) to evaluate students' 
E-Portfolio as a Tool for Professional Development and Assessment of the Prospective Singers

knowledge and skills in solving ill-defined problems in the real world (Li \& De Luca, 2014). Lombardi (2007) suggests that authentic tasks bear several features that orient students towards deep engagement with subject matter. These include the role of the context in defining tasks, complexity of tasks that necessitates management of the learning process, sustained investigation of problems, the use of multiple resources and perspectives to assist in problem-solving, and opportunities for collaboration and engagement in reflection.

At a minimum, authenticity is achieved when a student's evaluated work truly reflects their own achievements. In e-portfolio assessment, authenticity goes beyond the representation of authentic learning evidence to foster students' effective learning habits. Authenticity of e-portfolio assessment is pertinent to its capacity to afford meaningful learning experiences, which may include:

- learning by doing through tasks that require application of knowledge and skills for participating in professional practices;

- practicing higher-order thinking skills (e.g., reasoning, hypothesizing, synthesizing, and generalising) in solving complex problems;

- making students' thinking and actions accessible for self- and peerassessment, which helps students reflect on their actions;

- self-regulating one's learning progress with a view to transferring current learning to future tasks for long-term success;

- obtaining and using feedback at multiple time points in the learning process to improve performance;

- building relationships with peers and teachers to facilitate mutual support and collaborative learning.

The above-listed affordances are interrelated in that the first four invoke a cognitively challenging learning process for students, while such a process would entail students obtaining teacher and peer support through the last two affordances.

Honesty in e-portfolio assessment denotes the absence of plagiarism (copying from others' work without citing and acknowledging the original sources) in students' assessed work. The criterion of honesty is important because deterring plagiarism is essential in ensuring that the assessment procedure is fair to all students, and that students are educated to uphold integrity as a crucial aspect of academic work (Barbera, 2009).

To enhance honesty in students' e-portfolios, it is useful to require students to submit their e-portfolios to online plagiarism detection tools (e.g., Grammarly, Plagtracker, or Turn-it-in. A further step would be to strengthen the validity and reliability of e-portfolio assessment. This can be done by making assessment objectives clear to students, explaining the levels of assessment standards in rubrics, and demonstrating exemplars of completed e-portfolios. Students can also be encouraged to engage in productive learning, such as applying higher-order thinking skills and employing an investigative approach to problems, which are recognized as effective means for reducing plagiarism (Lombardi, 2007). 
In sum, ensuring authenticity and honesty in students' e-portfolios requires teachers' effort to integrate e-portfolio assessment into their curriculum and teaching as well as students taking self-responsibility for learning. While it is important to meet the criteria of robust e-portfolio assessment, teachers and universities also need to give careful consideration to the pedagogic, administrative, and technical factors that may be facilitative or hindering in implementing e-portfolios.

There are various factors that may influence the effectiveness of adopting eportfolios in higher education, which must be addressed so that e-portfolios can be recognised as a device of digital assessment. A university's technological infrastructure, technical support, as well as teachers' and students' familiarity and confidence with learning and teaching in a technology-rich environment can all impact the effectiveness of e-portfolios (Heath, 2005). With technological advancements, difficulties related to the above-mentioned factors might arguably fade over time. However, several major factors that are related to the pedagogical facet of e-portfolio implementation are likely to continue challenging users.

The first pedagogical factor is related to the possibility that students' motivation for engaging with e-portfolios may be hampered because of the workload involved. Students cannot be expected to build their e-portfolios simply as an add-on to their existing workload, regardless of whether e-portfolios are designed as an optional or mandatory task (Tosh, Light, Fleming, \& Haywood, 2005). Admittedly, constructing e-portfolios takes time (Heath, 2005), which makes it all the more important to clarify the purposes for implementing e-portfolios in order to boost students' motivation (Tosh, Light, Fleming, \& Haywood, 2005). To help make these purposes clear, three facilitative measures can be undertaken. To begin with, students can be shown exemplars of their peers' good e-portfolios that demonstrate the standards of quality required; such concrete examples that can give students the confidence necessary to achieve the standards (Lombardi, 2007). In addition, students can be given specific guidelines for allocating suitable time and making steady progress to finish the subtasks of their e-portfolios (Li \& De Luca, 2014). Lastly, teachers should help students to appreciate how the e-portfolio process contributes to their academic, professional, and personal development. In this way, students are more likely to actively engage with eportfolios and thus achieve quality learning outcomes (Strudler \& Wetzel, 2005).

The second pedagogical factor is derived from the dual roles of e-portfolios being used as summative and formative assessment of student learning, which may possibly result in students overlooking the role of e-portfolios in fostering their learning progress. Too often, the adoption of e-portfolios prioritises their role in assessment of learning, overshadowing their potential for assessment for learning (Chang, Liang, \& Chen, 2013). Although linking e-portfolios to summative assessment is often considered a motivating factor for students to take e-portfolios seriously (Lorenzo \& Ittelson, 2005), it is equally important to ensure that e-portfolios are not treated by students simply as an episodic assignment or a "file cabinet", which obstructs students' in-depth understanding of their learning experiences and practices being documented. Therefore, to fully realise the learning potential of e-portfolios, it is fundamental to 
E-Portfolio as a Tool for Professional Development and Assessment of the Prospective Singers

help students understand the construction of e-portfolios as a meaningful process of scaffolding their learning (Chang, Liang, \& Chen, 2013).

The third pedagogical factor has to do with the possibility of certain students lacking the capacity for self-reflection which is necessary for achieving quality learning outcomes through building e-portfolios. Successful uses of e-portfolios as an approach to assessment for learning inevitably ascribe a key role to student's reflections, and students cannot be expected to know how to engage in reflective practice without adequate coaching by their teachers (Barbera, 2009). Self-reflection is not just about recapping what students have learned; more importantly, students need to be encouraged to become self-aware of their learning progress, set worthwhile and achievable goals (such as by signing up learning contracts), and self-evaluate learning outcomes and areas of further improvement (Li \& De Luca, 2014). Self-reflection also requires students to be open to others' criticisms and feedback. Self-reflection in eportfolios has been reported by researchers to be cognitively and emotionally challenging (Barbera, 2009); thus, teacher support in students' reflective process is necessary (Lorenzo \& Ittelson, 2005). As discussed earlier in the current chapter, involving students in peer-feedback can help them to develop self-reflection skills (Green, Wyllie, \& Jackson, 2014). Thus, students should be supported through training on peer-feedback (e.g., workshops on how to provide constructive feedback) as a way to develop their capability for self-reflection.

Finally, the fourth pedagogical factor pertains to potentially insufficient teacher guidance and support, which may leave students struggling with learning difficulties unassisted. On the one hand, teachers in higher education are required to fulfil teaching, research and administrative duties, which can possibly reduce their willingness to provide regular feedback and guidance (Chang, Liang, \& Chen, 2013). On the other hand, studies have found that some teachers are lacking in skills for utilising the pedagogical functions of e-portfolio systems (Peacock et al., 2010). Without sufficient teacher commitment and capacity in giving students learning support, students may be unaware of essential guidelines and standards on e-portfolios. Thus, to encourage teachers' commitment to and capacity for providing learning support, programme/course teams may pay attention to allocating sufficient time and workload to teachers' provision of such learning support through consultations and/or workshops for students; then at the institution level, training via seminars, workshops and short teaching development programmes on the pedagogical use of e-portfolios may be arranged for teachers (Li \& De Luca, 2014).

Apart from the factors related to pedagogical issues discussed above, studies have also reported different administrative and technical factors that are crucial for successful e-portfolio implementation. Such factors may include institutional leadership and policy, up-to-date technological infrastructure, training and support for teachers and students on the functions of e-portfolios through workshops and consultation, and administrators' sensitivity to teachers' and students' needs for such support (Wetzel \& Strudler, 2005). These factors can either facilitate or create barriers 
E-Portfolio as a Tool for Professional Development and Assessment of the Prospective Singers

to e-portfolio implementation, depending on how they are addressed by HEIs. These factors should be considered in tandem with pedagogical factors in order to enhance teachers' and students' capacity and enthusiasm for using e-portfolios (Barbera, 2009).

The conclusions and the perspectives of further research. The potential of eportfolio design and development are far reaching. Students once engaged in the creation of e-portfolios continue to work on their portfolios and create communities of learners through exchange of ideas, sharing and online discussions. To sum up, this paper has mainly examined the major pedagogical factors that may potentially influence the effective implementation of e-portfolios. It has been made clear that at the macro level, meaningful adoption of e-portfolios must be accompanied by a shift in the curriculum towards greater emphasis on students' self-management, independent thought and self-reflection. Then, at the micro level, teacher's re-alignment of assessment and teaching strategies with the curriculum can be achieved. The abovediscussed pedagogical factors are further considered in the next studies by suggesting the strategies that can help address such factors in implementing e-portfolios as digital assessment tools.

\section{REFERENCES}

1. Barbera, E. (2009). Mutual feedback in e-portfolio assessment: an approach to the netfolio system. British Journal of Educational Technology, 40(2), 342-357. doi:10.1111/j.14678535.2007.00803.x

2. Chang, C.-C., Liang, C., \& Chen, Y.-H. (2013). Is learner self-assessment reliable and valid in a web-based portfolio environment for high school students? Computers \& Education, 60(1), 325334.

3. Green, J., Wyllie, A., \& Jackson, D. (2014). Electronic portfolios in nursing education: A review of the literature. Nurse Education in Practice, 14(1), 4-8 5p. doi:10.1016/j.nepr.2013.08.011

4. Heath, M. (2005). Are you ready to go digital? The pros and cons of electronic portfolio development. Library Media Connection, 23(7), 66-70.

5. Heinrich, E., Bhattacharya, M., \& Rayudu, R. (2007). Preparation for lifelong learning using ePortfolios. European Journal of Engineering Education, 32(6), 653-663. doi:10.1080/03043790701520602

6. Li, J., \& De Luca, R. (2014). Review of assessment feedback. Studies in higher education, $39(2), 378-393$.

7. Lombardi, M. M. (2007). Authentic learning for the 21st century: An overview. Educause learning initiative, 1(2007), 1-12.

8. Lorenzo, G., \& Ittelson, J. (2005). An overview of e-portfolios. EDUCAUSE Learning Initiative. Advancing learning through IT innovation. EDUCAUSE. Retrieved from https://net.educause.edu/ir/library/pdf/ELI3001.pdf

9. Peacock, S., Gordon, L., Murray, S., Morss, K., \& Dunlop, G. (2010). Tutor response to implementing an ePortfolio to support learning and personal development in further and higher education institutions in Scotland. British Journal of Educational Technology, 41(5), 827-851.

10. Strudler, N., \& Wetzel, K. (2005). The diffusion of electronic portfolios in teacher education: issues of initiation and implementation. Journal of research on technology in education, 37(4), 411-433.

11. Tosh, D., Light, T. P., Fleming, K., \& Haywood, J. (2005). Engagement with electronic portfolios: Challenges from the student perspective. Canadian Journal of Learning and Technology, 31(3), 1-19. 
E-Portfolio as a Tool for Professional Development and Assessment of the Prospective Singers

\title{
ЕЛЕКТРОННЕ ПОРТФОЛІО ЯК ЗАСІБ ПРОФЕСІЙНОГО РОЗВИТКУ І ОЦІНЮВАННЯ МАЙБУТНІХ СПІВАКІВ
}

\author{
Дмитро Лсвіт \\ кандидат філософських наук, доцент, \\ Київський університет імені Бориса Грінченка, \\ Київ, Україна \\ ORCID ID 0000-0003-3237-6427 \\ d.lievit@kubg.edu.ua
}

\begin{abstract}
Анотація. У статті розглядається роль електронних портфоліо як інструментів цифрової оцінки для підвищення якості результатів навчання у вищих навчальних закладах. Електронні портфоліо використовують потенціал цифрових технологій для підтримки самоконтролю студентів, самооцінки та обміну знаннями. Таким чином, зазначено, що електронні портфоліо сприяють покращенню навчання майбутніх співаків. 3 іншого боку, існуючі дослідження також виявляють проблеми для викладачів університетів при оцінюванні е-портфоліо. Питання використання електронних портфоліо наразі обговорюється у вітчизняних та зарубіжних дослідженнях (Д. Алфімов, Н. Михайлова, М. Остренко, О. Пічкур, Н. Савіна, I. Шалигіна, E. Heinrich, M. Bhattacharya, R. Rayudu, S. Peacock, L. Gordon, S. Murray, K. Morss). Щоб сформулювати стратегії оптимізації навчального потенціалу електронних портфоліо, проаналізовано наукову й методичну літературу з метою вирішення дослідницького питання про те, як електронні портфоліо використовуються як інструменти цифрової оцінки для підвищення якості результатів навчання у вищій освіті.

У статті представлено огляд електронних портфоліо як інструментів цифрової оцінки. Запропоновано типологію електронних портфоліо для аналізу ситуацій їх застосування у вищій освіті. У статті висвітлено дві основні можливості електронних портфоліо, а саме: розширення навчальних можливостей студентів; зворотній зв'язок та інтерактивність за допомогою цифрових технологій. Схарактеризовано виклики та можливості електронних портфоліо в дотриманні загальноприйнятих критеріїв оцінки, включаючи: надійність, обгрунтованість, достовірність та чесність. Розглянуто основні педагогічні фактори, що впливають на використання електронних портфоліо як цифрового оцінювання. Автор розрізняє такі фактори: мотивацію студентів до залучення до електронних портфоліо, подвійну роль електронних портфоліо в оцінці навчання та оцінювання для навчання, можливості для студентів, яким не вистачає саморефлексії, потенційно недостатнє керівництво та підтримка викладачів.
\end{abstract}

Ключові слова: електронне портфоліо; вища освіта; майбутні співаки; оцінка; критерії; педагогічні фактори.

\section{СПИСОК ВИКОРИСТАНИХ ДЖЕРЕЛ}

1. Barbera, E. (2009). Mutual feedback in e-portfolio assessment: an approach to the netfolio system. British Journal of Educational Technology, 40(2), 342-357. doi:10.1111/j.14678535.2007.00803.x

2. Chang, C. C., Liang, C., \& Chen, Y. H. (2013). Is learner self-assessment reliable and valid in a web-based portfolio environment for high school students? Computers \& Education, 60(1), 325334.

3. Green, J., Wyllie, A., \& Jackson, D. (2014). Electronic portfolios in nursing education: A review of the literature. Nurse Education in Practice, 14(1), 4-8 5p. doi:10.1016/j.nepr.2013.08.011 
E-Portfolio as a Tool for Professional Development and Assessment of the Prospective Singers

4. Heath, M. (2005). Are you ready to go digital? The pros and cons of electronic portfolio development. Library Media Connection, 23(7), 66-70.

5. Heinrich, E., Bhattacharya, M., \& Rayudu, R. (2007). Preparation for lifelong learning using ePortfolios. European Journal of Engineering Education, 32(6), 653-663. doi:10.1080/03043790701520602

6. Li, J., \& De Luca, R. (2014). Review of assessment feedback. Studies in higher education, 39(2), 378-393.

7. Lombardi, M. M. (2007). Authentic learning for the 21st century: An overview. Educause learning initiative, 1(2007), 1-12.

8. Lorenzo, G., \& Ittelson, J. (2005). An overview of e-portfolios. EDUCAUSE Learning Initiative. Advancing learning through IT innovation. EDUCAUSE. Retrieved from https://net.educause.edu/ir/library/pdf/ELI3001.pdf

9. Peacock, S., Gordon, L., Murray, S., Morss, K., \& Dunlop, G. (2010). Tutor response to implementing an ePortfolio to support learning and personal development in further and higher education institutions in Scotland. British Journal of Educational Technology, 41(5), 827-851.

10. Strudler, N., \& Wetzel, K. (2005). The diffusion of electronic portfolios in teacher education: issues of initiation and implementation. Journal of research on technology in education, 37(4), 411-433.

11. Tosh, D., Light, T. P., Fleming, K., \& Haywood, J. (2005). Engagement with electronic portfolios: Challenges from the student perspective. Canadian Journal of Learning and Technology, 31(3), 1-19.

Матеріали надійшли до редакції 26.04.2019 р. 